\title{
名水を訪ねて（74）徳島県の名水
}

\author{
島野安雄 $*$ ·堤 岑生**

\section{Visit to valuable water springs (74) Valuable water springs in Tokushima prefecture}

\author{
Yasuo SHIMANO * and Mineo TSUTSUMI **
}

\section{1. はじめに}

四国地方の「日本名水百選」については 8 カ所 が選ばれている（環境庁、1985）。この中で、徳 島県の江川の湧水は新井 (1991)、愛媛県のうち ぬき・杖の淵·観音水の 3 名水は井内ほか (1993)、 香川県小豆島の湯船の水は新見（1999）、高知県 の四万十川・安徳水の 2 名水は河野 (2002) が既 に当学会誌でそれぞれ取り上げてきている（図 1)。こうした中で、唯一残されたのが徳島県の 剣山に位置する「剣山御神水」である。本稿では、 この剣山御神水を含めた徳島県の名水に関して取 り上げることにした。

徳島県の名水については、先に挙げた江川の湧 水や剣山御神水の他にも数多くの名水のあること が知られている。徳島県においては、県独自に 「とくしま水紀行50選」を選んでいる（徳島県、 1999）。その内訳は湧水・井戸水等の地下水が17 力所、河川水や渓谷の水が18力所、滝の水が15力 所である。これらの地下水や流水の中からいくつ か取り上げることにする。また、四国は弘法大師 が生まれ育ち修行に励んだ所で、「弘法水伝説」 に因んだ水も多く、四国 4 県では157カ所あり、
このうち徳島県には34力所に存在しているという （河野、2002）。この弘法水は、四国霊場八十八力 所巡りのいくつかの寺院やその他にも存在してお り、それらについても取り上げる。

\section{2. 自然環境}

徳島県の自然環境は、主として吉野川と四国山 地によって特徽づけられる。吉野川は高知県北部 の瓶ヶ森山 $(1989 \mathrm{~m})$ に水源を発する全長 $194 \mathrm{~km}$ 、 流域面積3750 $\mathrm{km}^{2}$ の四国一の大河である。吉野川 は上流域では東に向かって流れるが、途中で向き を北に変えて四国山地を横断し、峡谷の景勝地と して有名な大歩危・小歩危の横谷を作っている。 その後は流路をまた東に変えて流れ、細長い三角 形のくさび状をした德島平野を形成した後に紀伊 水道へと注いでいる。そして、四国山地は中央構 造線の隆起造山運動で生まれた山々で、東西方向 に連なっている。しかし、中央付近で吉野川が間 を割るようにして南北に横切っており、四国山地 を東と西に分けている。すなわち、四国山地の東 側が剣山系で、西側が石錧山系である。したがっ て、剣山は剣山系のほぼ中央に推えていることに

文星芸術大学（

Bunsei University of Art

** 全国地下水利用対策団体連合会 


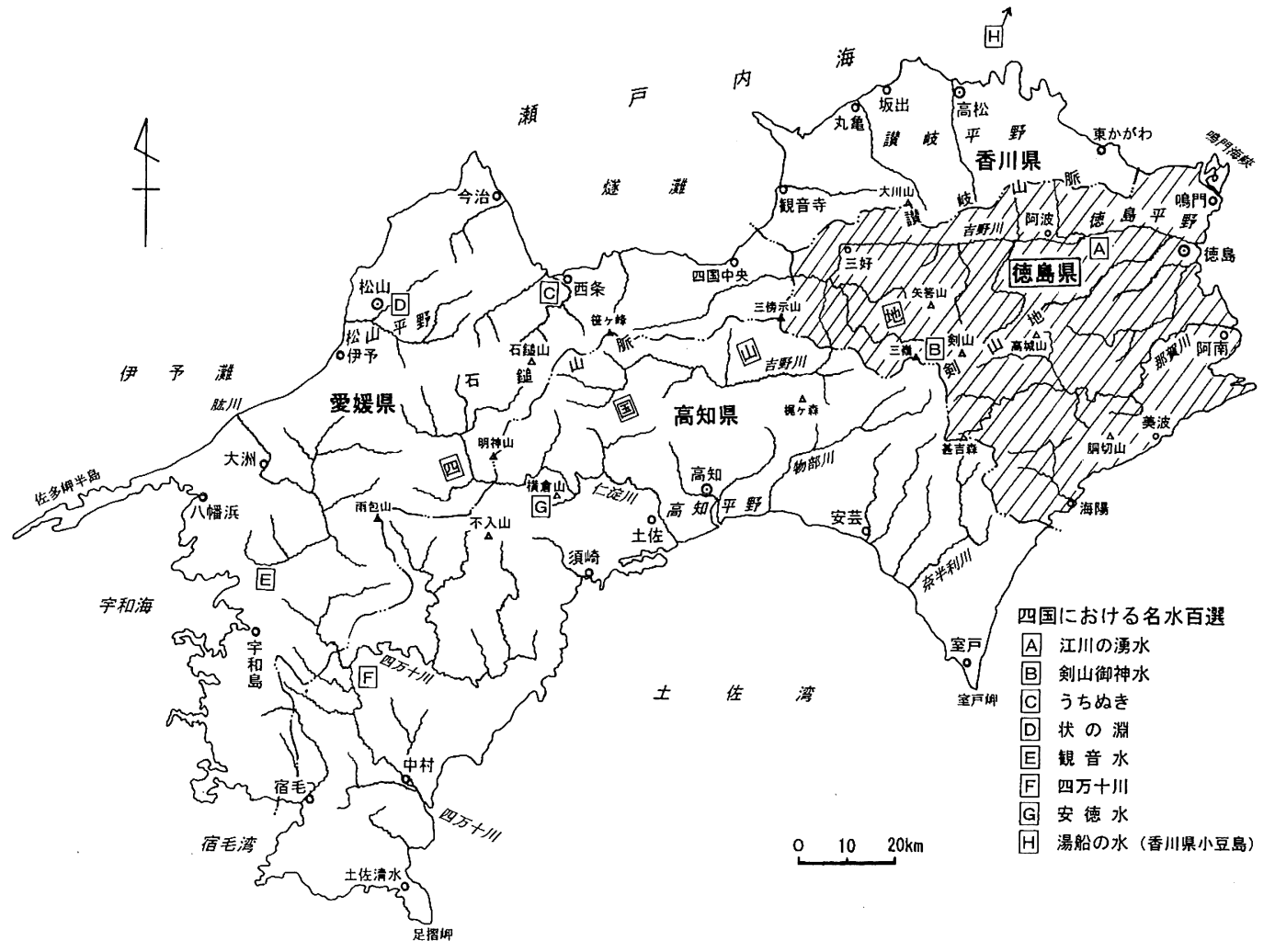

図 1 四国地方の名水百選

\section{なる（図 1)。}

まず、四国の地体構造や地質についてみると、 全般的には東西性の走向をもち、東西に延びる帯 状の分布を成しているのが特徴で、主に先新第三 紀の地層である領家帯・和泉帯・三波川帯・秩父 带・四万十帯などに大別される（図 2 )。徳島県の 地質もほぼこれにしたがって分布している（図 3 )。ここでは須鎗ほか（1991）や太田ほか （2004）などを参照して述べる。

和泉帯は中央構造線の北側に位置する白亜紀の 堆積岩類で、砂岩・泥岩を主とし、讃岐山脈や高 縄半島南部の山々を構成している。これらの山地 の北側には領家帯の花崗岩類が分布している。こ れに対して、中央構造線の南側に位置する三波川 帯は高圧低温型の変成岩類で、各種の結晶片岩か らなり、四国山地の春梁部を構成している地層で ある。変成岩の源岩は、泥岩・砂岩・火山岩など で、その年代は古生代石炭紀から中生代ジュラ紀 にわたり、特にジュラ紀のものが多いとされてい
る。三波川带の南縁に沿っては、火山岩や火砕岩 の変成した緑色岩類の多い部分（御荷鉾带と呼ば れる）も分布している。そして、三波川帯の南側 に秩父帯がある。秩父帯は低変成の堆積岩類から なり、三波川帯とは断層で接している。この堆積 岩類は、かつては全体が古生層とされていたが、 近年の微化石等の調査・研究によって、ペルム紀 〜ジュラ紀のチャート・塩基性火山岩類とジュラ 紀の夕ービダイト性の砂岩・泥岩からなり、ジュ ラ紀後期に日本列島に付加した地層であることが わかっている。この地層の中には石炭紀〜ペルム 紀中期の石灰岩が点在しており、三波川帯とほぼ 同時代のよく似た堆積岩からなる。また、この秩 父带の中には、蛇紋岩・シルル〜デボン紀の石灰 岩・オルドビス紀の花崗岩や変成岩などからなる 黒瀬川構造带と呼ばれる地層がある。この地層は 広い範囲にわたって狭い帯状またはレンズ状に断 続して分布している。秩父帯の南側には、仏像構 造線と呼ばれる衝上断層を隔てて四万十帯があ 


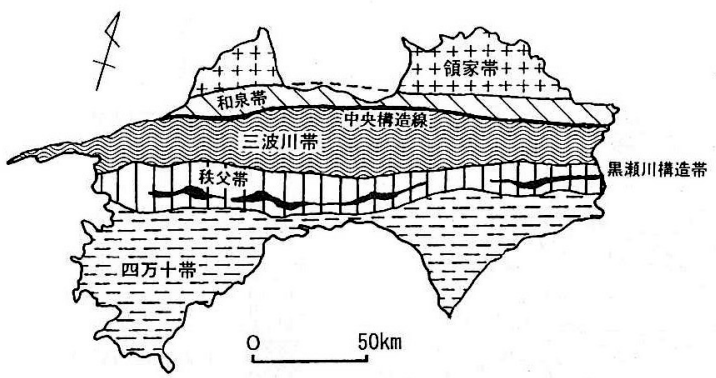

図 2 四国の地体構造

る。この四万十帯の地層は、西日本の帯状構造の 中では最も南に位置しているもので、白亜紀・古 第三紀・新第三紀の地層からなる付加体堆積岩類 である。この付加体は、破砕された泥質の岩石の 中に遠洋性のチャート・頁岩や火山岩（主として 枕状溶岩などからなる玄武岩）が大小のブロック となって含まれているメランジェ層と、その上に 重なる厚い夕ービダイト性の砂岩や泥岩とが単位 となって、繰り返し堆積している。この四万十带 の地層を調べてみると、どこでも北に向けて傾斜 している。地層の傾きと堆積物によって考えられ る四万十带の年代の新旧は、上部ほど新しいとい う一般的な層序からすれば、本来は北側の地層ほ ど新しいはずである。しかしながら、四万十帯は 実際には北ほど古く、南へ行くほど新しい。これ は一般的な地層の堆積構造と年代との関係では逆 であり、この特徽ゆえに、長い間「謎の地層」と 呼ばれてきた所以でもある。すなわち、四万十帯 の地質構造は、海洋プレートの移動に伴って、よ り新しい岩石が順に陸域側に押しつけられ付加ざ れて、北側が古く、南側に新しい地層が形成され た結果である。

図 3 の徳島県の地質図をみると、新しい第四系 の地層は吉野川や那賀川の下流域に分布するのみ で、新第三紀より前の時代の地層が大部分を占め ている。しかも県南の地域では付加体の堆積岩類 でほとんどが構成されている。これに対して、吉 野川下流域の北側は讃岐山脈で限られ、その南麓 部には中央構造線が東西方向に走っている。讃岐 山脈は砂岩・泥岩を主とする和泉層群で構成さ れ、風化や侵食が進み、山麓部には局状地性の砂 礫堆積物が堆積している。バッドランド地形とし て知られる阿波市の “土柱” も隆起扇状地や崖錐
の砂礫層が雨水などによる侵食を受けてできた奇 勝景観である。四国山地東部の剣山系の山々は三 波川帯と秩父帯からなり、第四紀を通してドーム 状の緩やかな隆起を続けてきており、山地の起伏 は東西性の地質構造を反映したものとなってい る。四国第 2 の高峰である剣山 $(1955 \mathrm{~m})$ の周囲 には、塔丸 $(1713 \mathrm{~m}) \cdot 丸$ 笹山 $(1712 \mathrm{~m}) \cdot$ 赤帽子 山 $(1611 \mathrm{~m}) \cdot$ 丸石 $(1684 \mathrm{~m}) \cdot$ 一ノ森 $(1879 \mathrm{~m})$ な どの山々が分布しているが、剣山の山頂やそれら の山々を結ぶ稜線部は比較的なだらかであり、そ して風が強いためにササ原が広がり亜高山帯の風 衝草原の植生群落がみられる。また、剣山を取り 巻く山地の地形は、地体構造を反映して、全般的 に東西方向に延びる水系とこれに直交するように 発達する南北方向の水系とによって区切られてい る。水系の谷壁斜面の傾斜は、東西方向の谷に面 するものが緩傾斜であり、南北方向の谷に面する ものが急傾斜となっている。ところで、吉野川中 流部の大歩危・小歩伦という峡谷は、四国山地が 隆起する速度よりも吉野川の侵食力の方が勝って いたために、川が山地を横切る形である横谷の形 状を示している。

吉野川以外の河川として、剣山の南簏に発する 那賀川は、全長 $125 \mathrm{~km}$ 、流域面積 $874 \mathrm{~km}^{2}$ を有し、 県南の半分の地域を流れている徳島県第 2 の大河 である。そして、この那賀川や剣山東麓に発する 穴吹川および県南西部を流れる海部川について は、四万十川以上の清流河川であると言われてい る（池田、2005）。また、県南の太平洋沿岸地域 は、北東〜南西方向に延びる岩石海岸が連なって いるが、その海岸線は隆起・沈降や差別侵食の影 響を受けて変化に富んだ景観を示している。な お、徳島平野のデル夕地带では、1960年代に開発 が進んで景観が変貌したり、地下水の大量揚水に よる地盤沈下や塩水化に伴う塩害を受ける水田も でていた。しかし、近年は揚水量も減って地下水 位が上昇してきたりして、中には自噴の復活した 井戸も現れているという（堤、2005; 井内、 2005)。

次に、徳島県の水文・気象等に関してみると、 四国山地が東西に延びていることから、その北側 の吉野川河谷では降水量がやや少なく、年降水量 は $1500 \mathrm{~mm}$ 程度である。これに対して、四国山地 

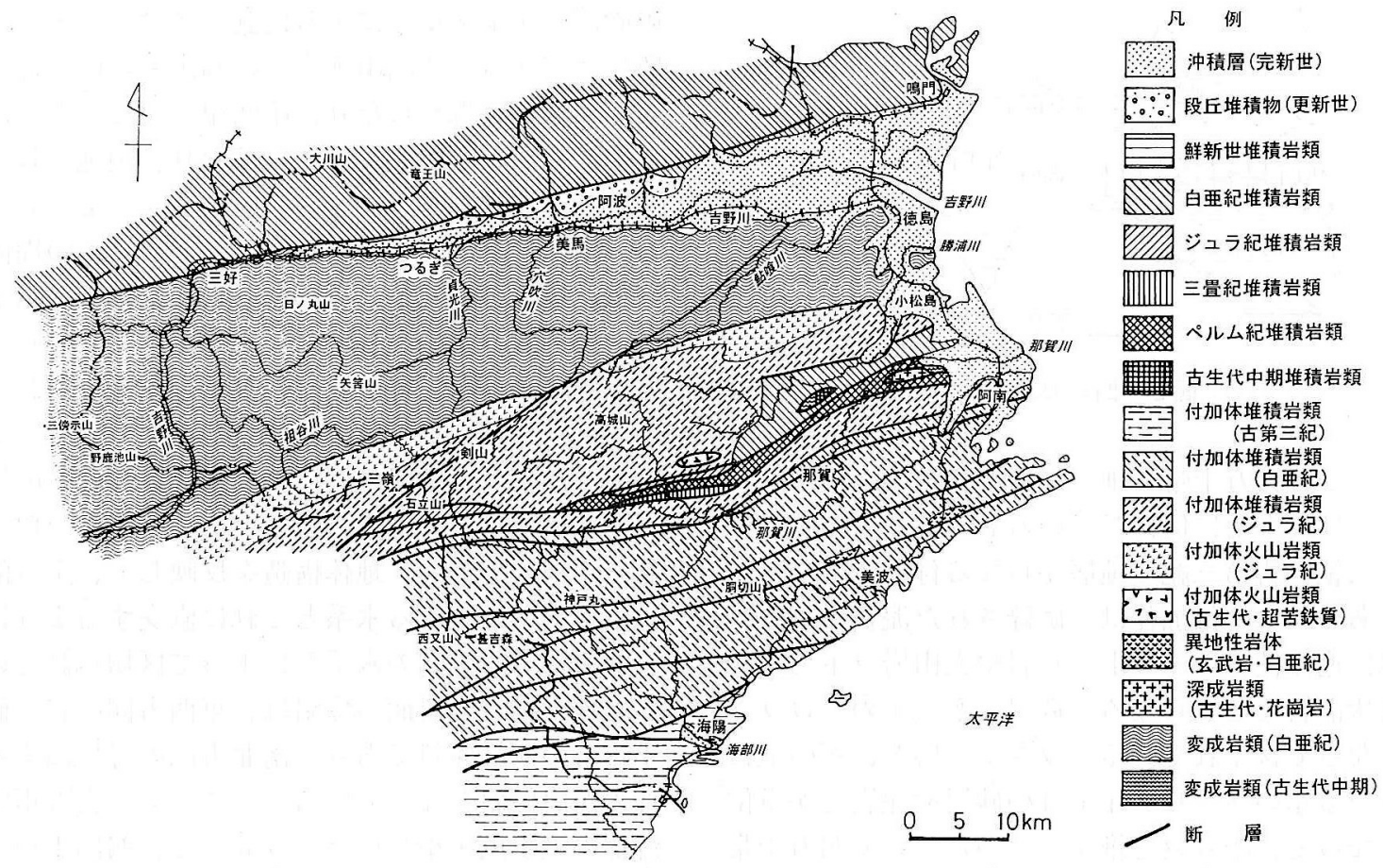

図 3 德島県の地質図（地質調查所、1992をもとに作成）

から南の太平洋側は、冬期には四国山地の影響で 季節風が遮られ降水量は少なくなるが、前線が南 岸に接近する 4 月頃から雨が急に多くなり、梅雨 期や台風期には強い雨が大量に降り、場所によっ ては年降水量が3000mm を超える。ちなみに、県 内の各地点の平均気温と年降水量の平年值（1971 〜2000年）についてみると、徳島市で $16.2^{\circ} \mathrm{C} 、$ $1541 \mathrm{~mm}$ 、三好市池田で $13.9^{\circ} \mathrm{C} 、 1393 \mathrm{~mm}$ 、那賀 町木頭で $13.2^{\circ} \mathrm{C} 、 3037 \mathrm{~mm}$ 、海陽町宍喰で $16.3^{\circ} \mathrm{C} 、 3175 \mathrm{~mm}$ 、美波町 日和佐 で $16.4^{\circ} \mathrm{C}$ 、 $2550 \mathrm{~mm}$ 、および阿南市蒲生田で $16.2^{\circ} \mathrm{C}$ 、 1918mmである。

\section{3. 採水地点の状況}

今回、徳島県の名水として取り上げたのは、湧 水・井戸水などの地下水が 32 力所、滝や渓谷の水 などの渓流水・河川水が 8 力所の計 40 力所である (図 4)。これらの地点の標高に関してみると、海 抜 $1 \mathrm{~m}$ ほどの沿岸部の沖積地から剣山や次郎笈の 山頂下の水場の約 $1800 \mathrm{~m}$ まで、かなりの高低差が あった（表 1 )。これらの採水地点に関して、順
次、自然環境や周辺の状況および故事来歴などの 概要を説明しておくことにする。その際に、一部 は先に記した徳島県（1999）の案内書などを参照 して述べる。なお、平成の市町村大合併で名称の 変わった所も多く、本文中には旧名称も記入して おいた。

大平の湧水 (採水地点番号、No. 1) は、三好市 (旧三野町) 大平、大川山（1043m）の南西中腹に 位置する湧水である. 大平集落手前の道路脇の崖 から流れ出ていたが、水量はわずかであった。金 剛滝 (No. 2) は、三好市 (旧三野町) 加茂野宮か ら北に小さな渓流沿いに遡った所にある落差約 $40 \mathrm{~m}$ の滝である（写真 1)。遊歩道やせせらぎ公 園が整備されていて、市民の㮩いの場となってい る。な扮、この滝の下にも落差約 $20 \mathrm{~m} の$ 竜頭滝が 幜かっている。

鳴滝 (No. 3) は、つるぎ町 (旧貞光町) 猿飼を 流れる貞光川の切り立った渓谷に注ぐ渓流水に懸 かっている滝で、落差 $40 \cdot 25 \cdot 20 \mathrm{~m}$ の 3 段の滝か らなり、合わせた落差は県下随一を誇っている。 この鳴滝の懸かっている地点の少し上流側の貞光 川の河岸では、緑色片岩の岩層を横切って河川水 


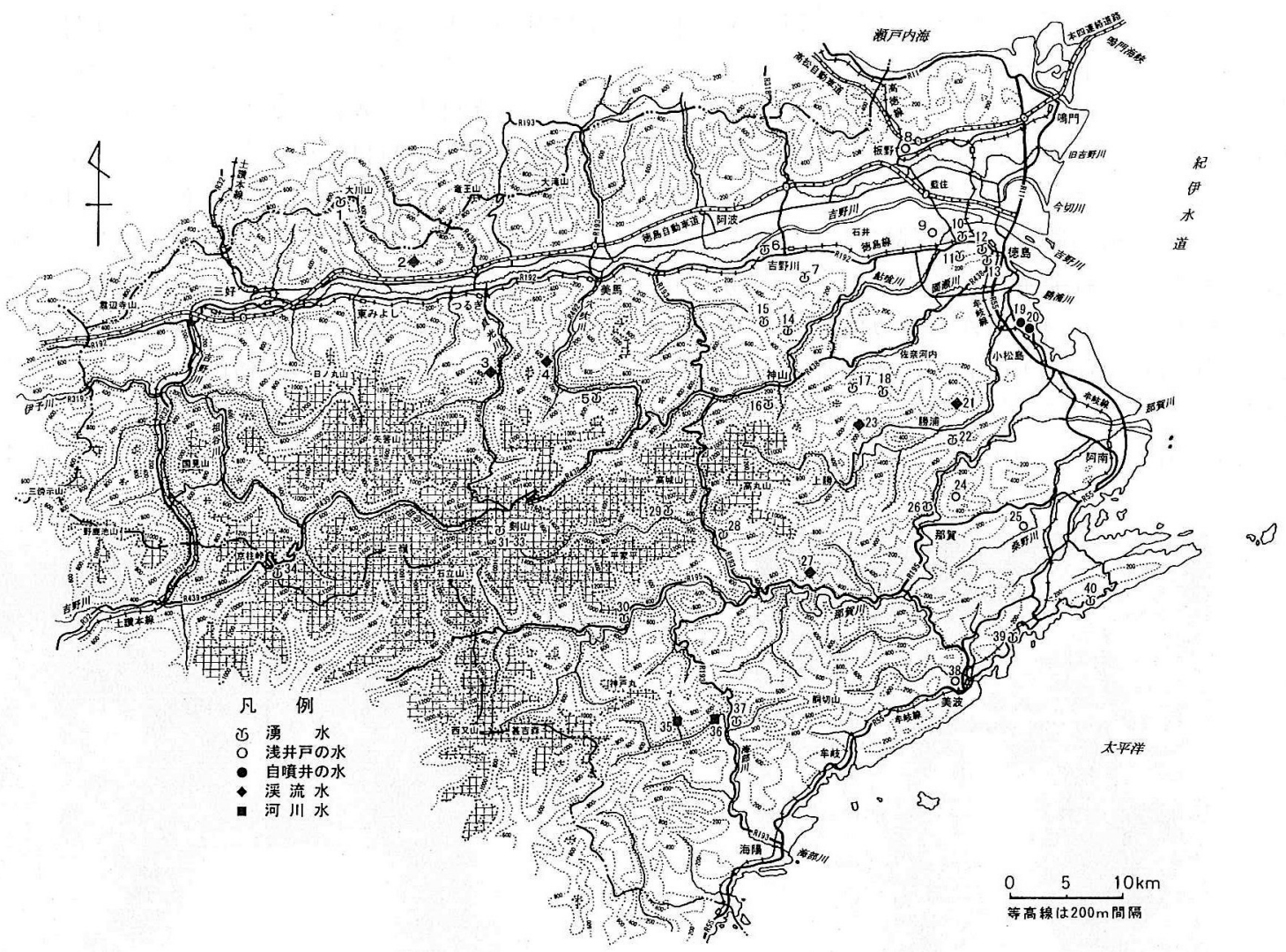

図 4 採水地点の位置図

が流れている所があり、土䔙と呼ばれる狭い釜状 の滝壷や歐穴などからなる峡谷が位置している。 閑定の滝（No.4）は、美馬市（旧穴吹町）左手に 位置し、友内山 (1073m) の東斜面から流れ出て いる溪流水に懸かっている滝で、穴吹川に注いで いる。川瀬の水 (No.5) は、美馬市（旧穴吹町） 川瀬の穴吹川に沿って走る国道492号線の道路脇 に流れ出ている水である。

江川の湧水 (No.6) は、吉野川市（旧鴨島町） 西麻植に湧き出していて「日本名水百選」に選ば れている清水である。吉野川の伏流水が堤防脇の 堤内地に湧出したもので、江川の水源となってい る。そして、この湧水は夏期に冷たく冬期に暖か いという水温異常で知られていて、これまでにも 度々取り上げられている（新井・佐倉、1980、新 井・横畠、1990、新井、1991など)。しかしなが ら、かつては気温と水温のズレの幅が半年ほど あったが、近年は 2 ヶ 月程に短くなってきて いるといわれている。龍王水 (No.7) は、吉野川
市 (旧鴨島町) 森藤にある公園内に整備されてい るもので (写真 2 )、もとは南側の山の中腹にお いて地滑り調査中に湧き出した水であって、そこ から約 $600 \mathrm{~m}$ の距離をパイプで引水してきたもの である。

黄金の井戸 (No. 8) は、板野町大寺にある四国 霊場第 3 番金泉寺の境内にある浅井戸である（写 真 3 )。聖武天皇の勅命により行基が開創し金光 明寺と称されたというが、その後に弘法大師が境 内に湧き出る黄金の霊水を発見したことにより金 泉寺と改められたとされている。面影の井戸 (No.9）は、德島市国府町にある四国霊場第17番 の井戸寺の境内にある浅井戸である。井戸寺は天 武天皇の勅願により674年に創建されたもので、 弘法大師が815年に人々が水に困っているのをみ て、錫杖で一夜にして井戸を掘って与えたという 由来がある。井戸は水大師堂の中にあって四角い 石造りの井桁からなり（写真 4)、時に参帱者が 自分の顔を映している風景も見られる。蔵清水 
（No.10）は、吉野川に注いでいる鮎喰川の伏流水 とされる水で、JR蔵本駅前の小公園に水場が整 備されている。この湧水については、古くは蔵本 城主小倉美濃守にまつわる「大蛇と水」という霊 異話があるとされている。

次に、徳島市の眉山の山麓部には、錦竜水・鳳 翔水・春日水・青龍水 ·雲龍水など多くの湧水が 分布していて、そのうちから 3 力所の湧水を採水 した。桐の水 (No.11) は眉山西麓の加茂名町にあ る湧水である。かつて江戸時代に金蓮寺跡の泉と して湧き出していた地下水があり、藩主のお茶の

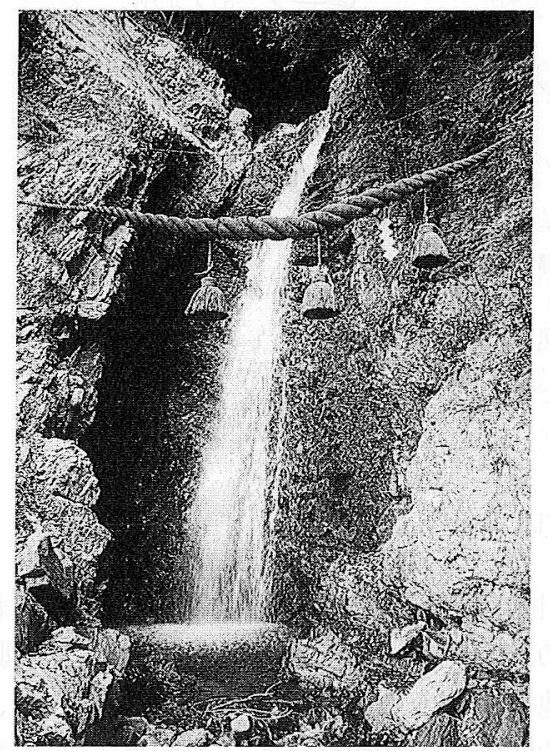

写真 1 金剛滝

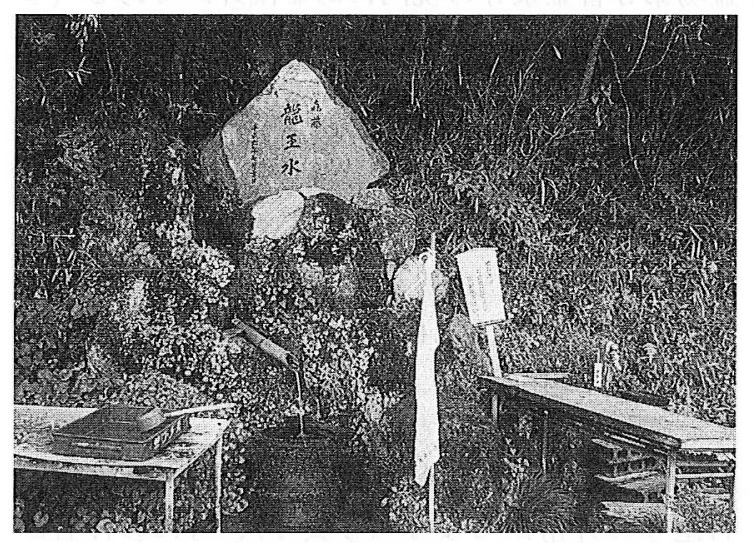

写真 2 龍王水
水に利用されていて、桐の水という名が付けられ ていたという。その後、平成元年に新たに試掘し たところ美味しい水が噴出したことから、桐の水 の名が復活して付けられたという経緯がある。錦 竜水 (No.12) は北東麓の寺町にあって、江戸時代 には藩公御用達の水と知られていた湧水で、水番 所をおいて保護されていたという。現在は写真 5 のように水場が整備されている。鳳翔水（No.13） は東麓の東山手町の瑞嚴寺境内にあって、やはり 昔は茶の湯として利用されていたという。

大泉小泉 (No.14) は、神山町阿川の二宮神社の

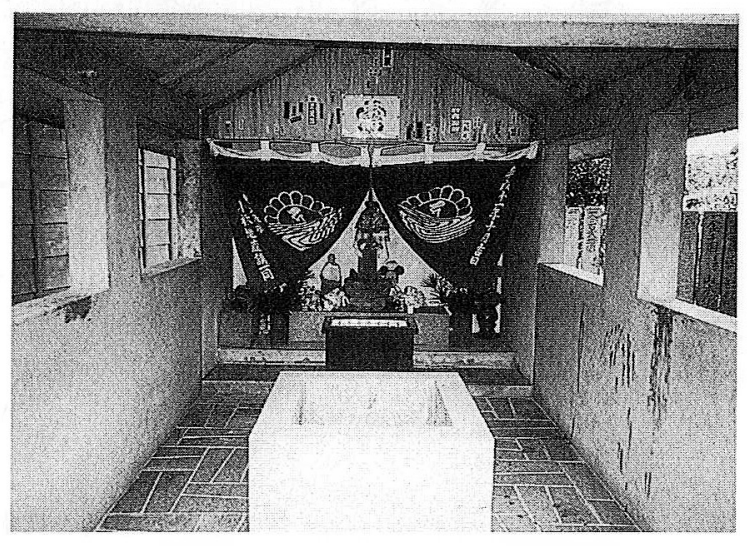

写真 3 黄金の井戸（金泉寺）

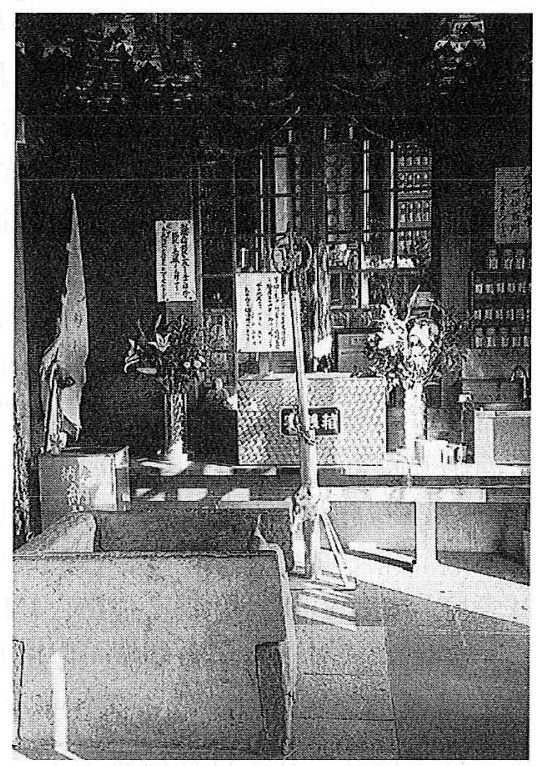

写真 4 面影の井戸 (井戸寺) 
西側にあって、共同井戸として使われている湧水 で、畳一枚分ほどの大きさに仕切られた大小 $2 つ$ の湧水池からなる（写真 6 ）。柳の水（No.15）は 神山町阿川の柳水庵境内に湧き出している清水 で、弘法水の一つでもある。天の中川（No.16） は、神山町高根の標高約 $730 \mathrm{~m}$ にある悲願寺境内 に湧き出している清水のことである。この水は $100 \mathrm{~m}$ ほど流れ下ると、日本の滝百選に選ばれて いる「雨乞の滝」の雌滝（落差45m）へと注いで いる。大川原高原の水 (No.17) は、佐那河内村の 大川原高原を走る林道の脇に湧き出している清水 である。命の水 (No.18) は、佐那河内村嵯峨の杖 立山 $(724 \mathrm{~m})$ の北側中腹の標高 $570 \mathrm{~m}$ にある徳円 寺境内に湧く水である (写真 7$)$ 。この寺は江戸 文政年間に徳円上人により開基されたもので、

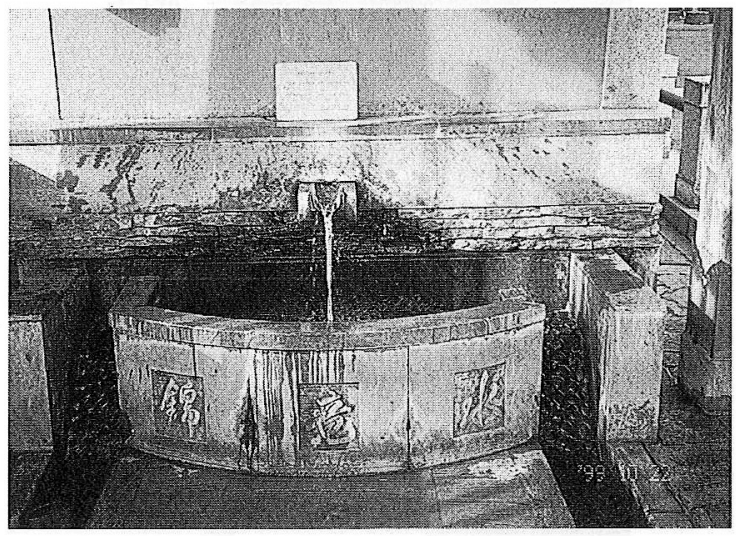

写真 5 錦竜水

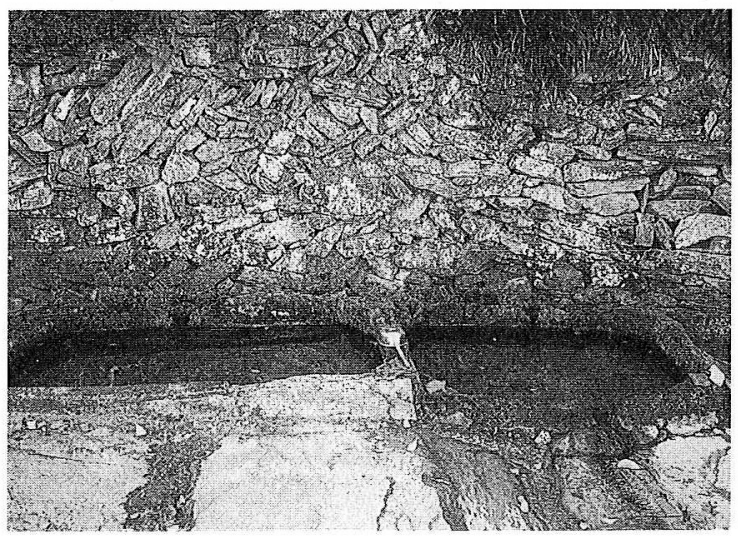

写真 6 大泉小泉
シャクナゲの花で知られている。

小松島市の平野部では、地下水が豊富なことか ら古くから多くの掘り抜き井戸が掘られてきた。 その中で宝寿水 (No.19) は、市内松島町にある地 蔵寺の境内に湧出している自噴水で、古くは阿波 藩主が来訪の折りに所望し賞賛したとされてい る。また、のぞみの泉(No.20)とは、近年、市民 有志がかつての掘り抜き井戸を再現し、JR 南小 松島駅前に設備した水場である。裹見の滝 (No.21) は、勝浦町星谷、中津峯山 $(773 \mathrm{~m})$ の中 腹に位置する四国霊場第19番立江寺の奥院である

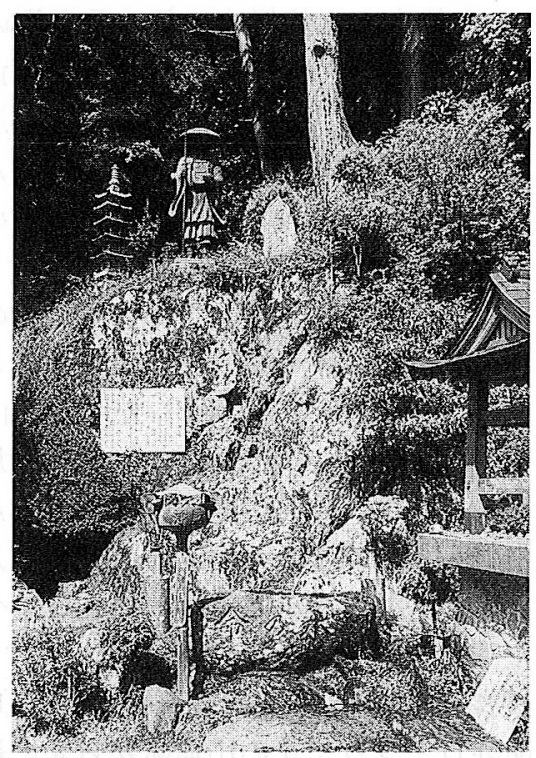

写真 7 命の水（徳円寺）

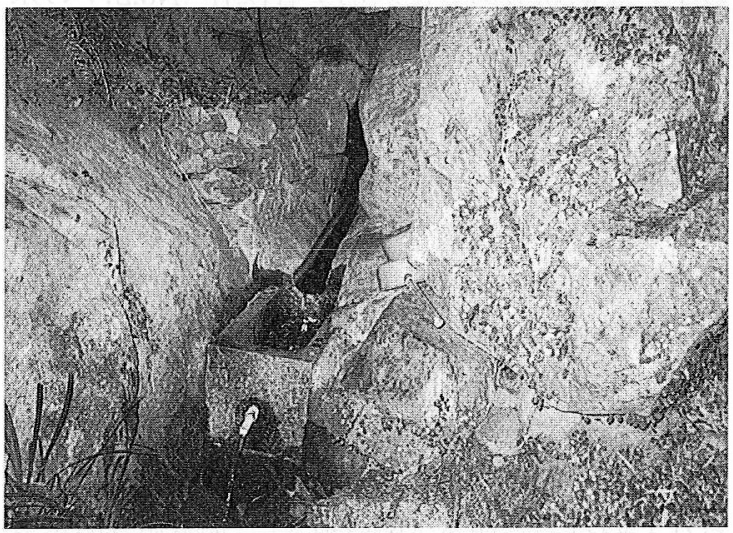

写真 8 水吞大師 
星谷寺の近くに懸かっている滝である（口絵写真 $\mathrm{B})$ 。滝の裏側に小さな洞らがあり、そこから流 れ落ちる滝の水を眺められることから裏見の滝と 云われている。水谷大師 (No.22) は、第20番鶴林 寺のある山の北麓、勝浦町生名を通る遍路道の傍 ら標高 $180 \mathrm{~m}$ の所に湧き出している清水である (写真 8)。灌頂ヶ滝 (No.23) は、上勝町灌頂滝に ある落差 $80 \mathrm{~m}$ ほどの滝である。別名「旭の滝」と いわれ、水量は少ないが、晴天の日にはこの滝を 五色の虹が彩り、不動の来迎と呼ばれる美しさが みられるという。

太龍寺の水 (No.24) は、阿南市加茂町龍山、標 高618m の太龍寺山に位置する第21番霊場の太龍 寺の境内にある井戸水である。太龍寺は桓武天皇 の勅願により798年に阿波国司の藤原文山が建立 したとされ、若き日の弘法大師が修行に励んだ地 として知られている。現在は、那賀町田野の所か らロープウェイが架けられていて、10分ほど乗る と寺に着くので行き易くなっている。白水の井戸 （No.25）は、第22番平等寺の境内にある浅井戸で ある。弘法大師が792年に開創した寺で、山号の 白水山医王院は弘法大師が祈䘠のために井戸を 掘ったところ、白い乳色の水が湧き出てきたこと により由来している。この白水の井戸水は万病に 効く「弘法の水」と崇められていて、本堂へ登る 石段の左下に位置している（写真 9 )。

水柱観音の水 (No.26) は那賀町 (旧鷲敷町) 田 野、太龍寺ロープウェイの山麓駅から北に那賀川 に沿って県道を $700 \mathrm{~m}$ ほど行った道端にある湧水 である。崖の上に社があり、すぐ近くには石灰岩 の小さな洞窟もあった。臼ヶ谷溪谷 (No.27) の水 は、那賀町 (旧上那賀町) 臼ヶ谷を流れる溪流水 である。御加持水（No.28）は、那賀町（旧木沢 村）木頭名にある黒滰寺の境内に湧く水で、別名 「黹加并の水」とも呼ばれている。この寺は弘法 大師が延暦年間に開基したとされ、古くから山岳 仏教の聖地と知られ、太龍寺の奥院となってい る。この湧水は寺の裏手の斜面（標高約 $760 \mathrm{~m} ） に$ あってコンクリートで囲われていて（写真10）、 弘法大師の大竜退治の伝説と関係があり、この霊 水を飲むとあらゆる厄難を払い難病が治ると伝え られている。長命水 (No.29) は、那賀町（旧木沢 村）横谷にあった四季美谷温泉前の岩間から湧き
出している清水である。現在、四季美谷温泉その ものは $1 \mathrm{~km}$ ほど下流の地点に移っていて、古い 建物たけが残っている状態となっている。かつて 温泉客に親しまれてきた岩清水は、道路を挟んで 反対側にあるが、水量がかなり少なくなってい た。歩危峡の湧水 (No.30) は、那賀町（旧木頭 村）和無田、那賀川の歩危峡と呼ばれる渓谷を 通っている国道195号線の道路脇の崖から湧き出 している清水である（写真11）。

四国山地東部の剣山系の主峰である剣山 (1955m) は、石錧山に次ぐ四国第 2 位の高峰で

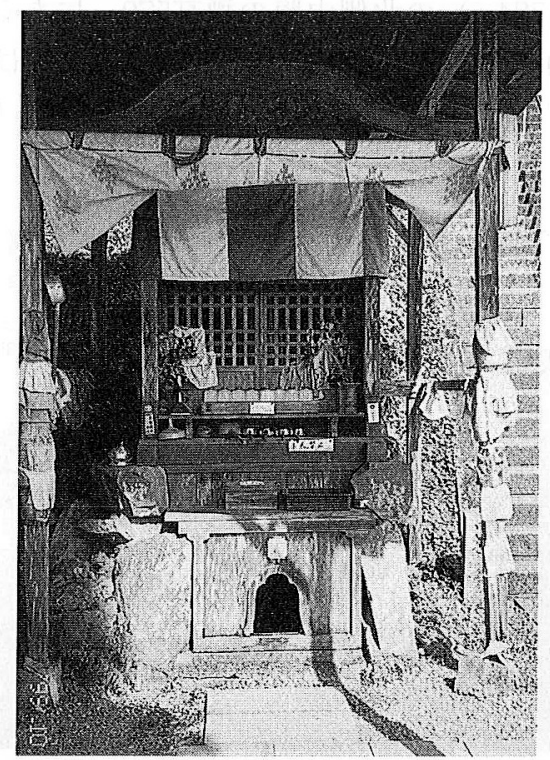

写真 9 白水の井戸 (平等寺)

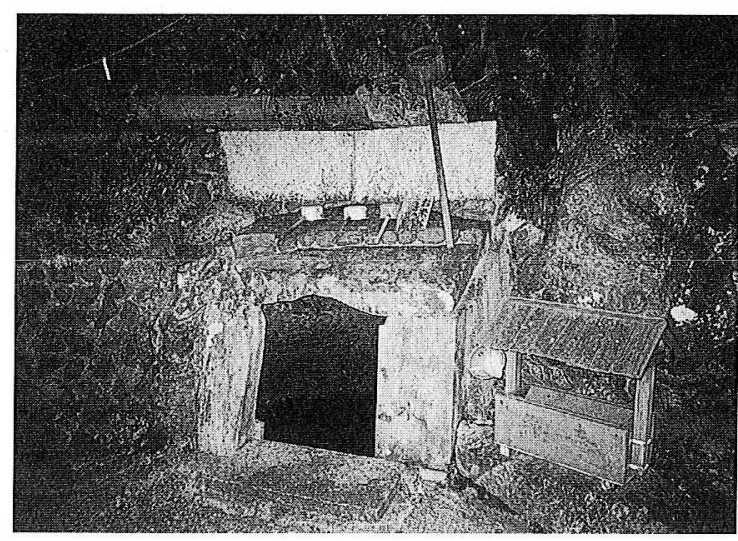

写真10 御加持水（黒滝寺） 
あるが、山頂部はその名に似合わない広々とした 草原からなる丸みを带びた台地状平坦面の地形を 呈している。登山口の見ノ越 $(1400 \mathrm{~m})$ からは、 山道の他に、登山リフトが標高 $1710 \mathrm{~m}$ 付近につく られた西島駅まで延びている（図 5 )。ここから はいくつもの山道が剣山の山頂に延びているが、 いずれも残り約 $250 \mathrm{~m}$ ほどの標高差を登れば山頂 に楽々と着くことができる。剣山は秩父帯の付加 体堆積岩類を主体に、石灰岩やチャートなどの異 地性岩体を含んだ山体で構成されている。そのた め、この山では石扊岩の岩塔や岩塊がみられる。 山頂の西側下に大剣神社が鎮座しているが、この

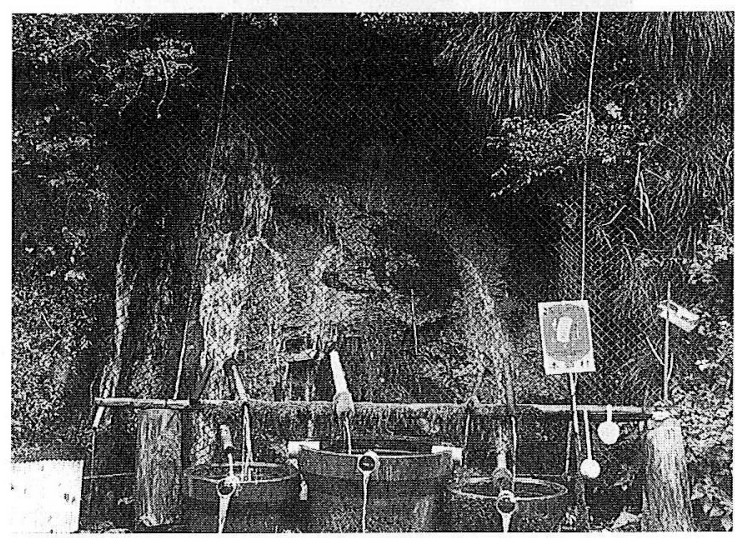

写真11 歩危峡の湧水

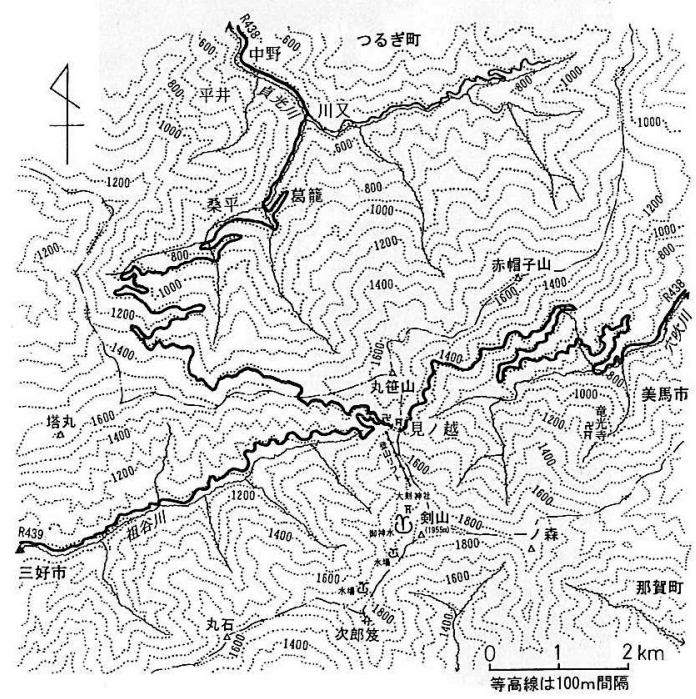

図 5 剣山周辺の位置図
神社は高さ $50 \mathrm{~m}$ もの石灰岩質の巨石の塔である “御塔石”を御神体としている（写真12）。この御 塔石の根元の部分から湧出しているのが剣山 御神水 (No.31) である。ここの標高は約 $1760 \mathrm{~m}$ で あり、山頂からは比高にして $200 \mathrm{~m}$ ほど下った所 に位置している。御神水は小さな社の脇に湧き出 しているが（口絵写真 A)、湧出量は毎分10惔程 度とわずかである。この御神水の所を過ぎて山道 を南へ少し向かうと、小さな流れの水場に着く。 これがもう一つの剣山の水場（No.32）である。さ らに、次郎䈔への山道を進み、山頂ではなく、右 手の山周りの方の道をとると、次郎笈の水場 (No.33) へと達する.ここでは小さな 2 本のパイ プから水が流れ落ちていた（写真13）。なお、こ れら 3 カ所の湧水はいずれも三好市（旧東祖谷山 村）に属している。京柱峠の水（No.34）とは、三 好市 (旧東祖谷山村) 樫尾、国道439号線の徳島. 高知県境となっている京柱峠（約 $1100 \mathrm{~m}$ ）の所に 引かれている水である。

海部川上流の鰻轟山（1046m）から流れ下る支 流には数多くの滝が奬かっている。その一つ本滝

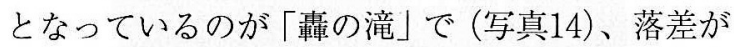
$58 \mathrm{~m}$ という四国一の大滝で、日本の滝百選にも選 ばれている。この滝の滝壼は奥まった所にあり、 周辺は修験道の行場になっている。轟の滝 （No.35）の水は、この滝喆の近くで採水した。な お、轟の滝の上流側には二重の滝・不動滝・横見 滝·丸㴊滝・大鳥小鳥滝・主十三才滝・鍋割りの 滝などの多くの滝が連続して懸かっており、総称 して轟九十九滝と呼ばれている。ところで、海部 川は 2 級河川であるが、日本有数の清流として知 られている。海部川（No.36）の河川水は、海陽町 (旧海南町) 皆ノ瀬で採水した。また、皆ノ瀬の 水（No.37）とは海陽町（旧海南町）皆ノ瀬に湧く 清水である。

肺大師の水（No.38）は、美波町（旧日和佐町） 奥河内、第23番薬王寺の境内にある井戸水であ る。聖武天皇の勅願により行基が開創し、その後 に弘法大師が厄除けの薬師如来を刻んで本尊とし たことにより、厄除けの根本道場として信仰され てきたという。井戸は本堂の左裹手に位置してい る（写真15）。満石神社（No.39）の水とは、美波 町（旧由岐町）木岐浦にある湧水である。別名 
「ごんげんさんの水」と呼ばれ、イボ取りや病気 快癒の霊水として信仰を集めている。御水大師 （No.40）は美波町（旧由岐町）阿部の海岸段丘の 上にある湧水で、弘法大師の修行の地と伝えられ る庵に湧き、眼病に効くとされている。

\section{4. 水質の特徵}

現地での調査は、古くは1990年に行い、それ以 降も時々行ってきているが、大半の地点では2005 年に採水を行った。採水調查に関して、水温・電

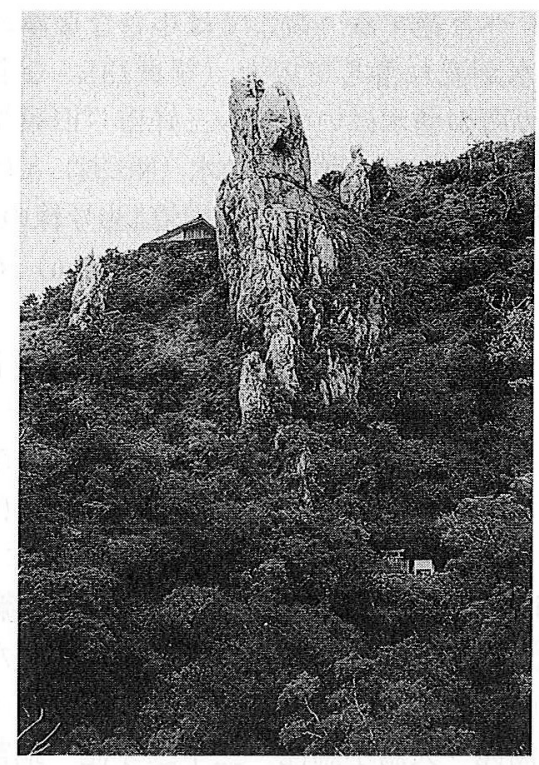

写真12 剣山の御塔石

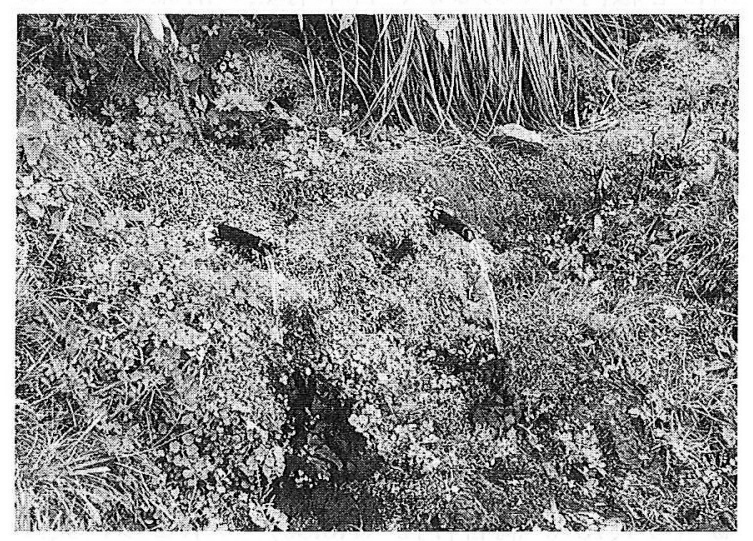

写真13 次郎笈の水場
気伝導度 $\left(25^{\circ} \mathrm{C}\right.$ に換算した值 $) \cdot \mathrm{pH}$ については現 地で採水時に測定した。採水したサンプルはポリ ビンに入れて持ち帰り、主要溶存成分である炭酸 水素 $\left(\mathrm{HCO}_{3}{ }^{-}\right)$) 塩素 $\left(\mathrm{Cl}^{-}\right)$. 硫酸 $\left(\mathrm{SO}_{4}{ }^{2-}\right)$ ) 硝 酸 $\left(\mathrm{NO}_{3}{ }^{-}\right) \cdot$ ナトリウム $\left(\mathrm{Na}^{+}\right) \cdot$ カリウム $\left(\mathrm{K}^{+}\right)$・

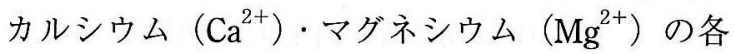

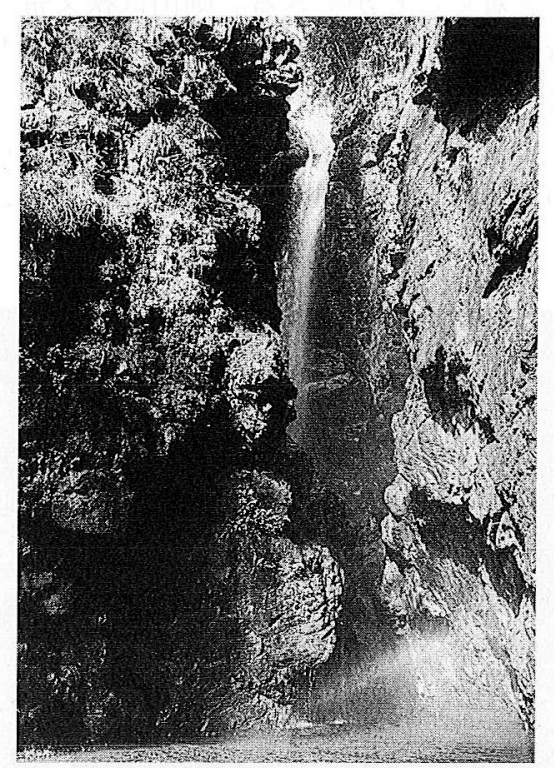

写真14 轟の滝

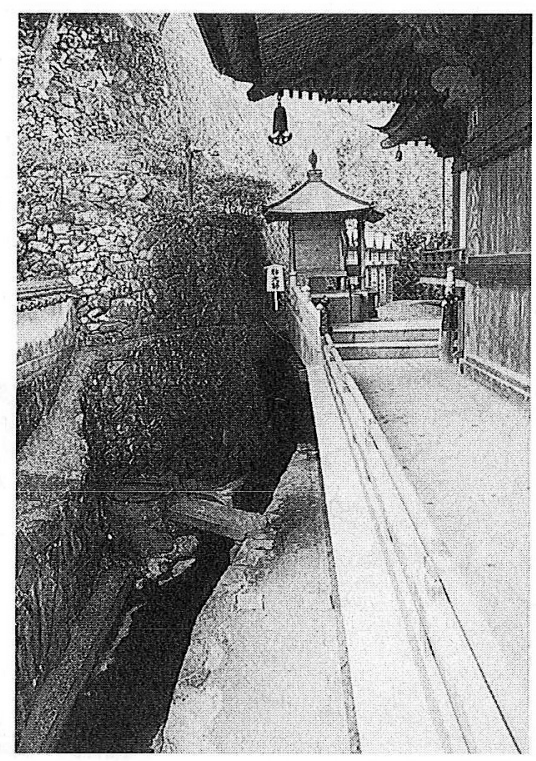

写真15 肺大師の水（薬王寺） 
イオン、およびケイ酸 $\left(\mathrm{SiO}_{2}\right)$ などについて分析 を行った。炭酸水素イオンについては希硫酸を用 いた4. 3Bx（アルカリ度）による滴定法で定量し た。その他のイオンについては、筑波大学におい て、㓌イオンがイオンクロマトアナライザー、そ して陽イオンおよびケイ酸についてはプラズマ発 光分光分析装置を用いて分析を行った。

それらの水質分析の結果を濃度 (mg/L) で示し たのが表 1 である。そして、水質分析した主要溶 存成分值をもとに、へキサダイアグラム表示とト リリニアダイヤグラム表示とで水質組成を示した のが図 6 である。なお、複数のサンプルのあった 蔵清水·錦竜水・鳳翔水. 剣山御神水については、 新しい採水年次のものを作図した。

まず、採水調査時での特徴についてみると、電
気伝導度については $100 \mu \mathrm{S} / \mathrm{cm}$ 以下が17カ所、 $100 \sim 200 \mu \mathrm{S} / \mathrm{cm}$ が19カ所、200 $\mu \mathrm{S} / \mathrm{cm}$ 以上が 4 カ 所と、低濃度の地点が多かった。水温は $7 \sim 20^{\circ} \mathrm{C}$ の範囲にあって、平均的にはほぼその地点の平均

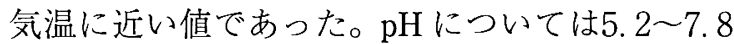
とかなり幅広い值を示していたが、弱酸性を示す 地点の方がやや多かった。

次に、各地点における水質の特徴についてみて みることにする。大平の湧水 (No.1) は全般的に 溶存成分量が少なく、 $\mathrm{Na}-\mathrm{HCO}_{3}$ 型の水質を呈し ていた。金剛滝 (No. 2 ) の水は、 $\mathrm{Ca} \cdot \mathrm{Na} \cdot \mathrm{HCO}_{3}$. $\mathrm{SO}_{4}$ などの溶存成分量が多く、組成としては $\mathrm{Ca}$ $\mathrm{HCO}_{3}$ 型に $\mathrm{Na}-\mathrm{SO}_{4}$ 型が加わった混合タイプといえ よう。鳴滝 (No. 3 ) の水は、 $\mathrm{Ca}$ と $\mathrm{HCO}_{3}$ 成分の割 合が高く、組成としては $\mathrm{Ca}-\mathrm{HCO}_{3}$ 型を示す。閑

表 1 水質分析結果

\begin{tabular}{|c|c|c|c|c|c|c|c|c|c|c|c|c|c|c|c|c|c|c|}
\hline 番号 & 称 & 所 在 & \begin{tabular}{|l} 
摽高 \\
$(\mathrm{m})$
\end{tabular} & 源 & 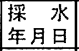 & \begin{tabular}{|c|} 
電導度 \\
$(\mu \mathrm{S} / \mathrm{cm})$ \\
\end{tabular} & \begin{tabular}{|l|} 
水温 \\
$\left({ }^{\circ} \mathrm{C}\right)$ \\
\end{tabular} & $\mathrm{H}$ & \begin{tabular}{|c|}
$\mathrm{HCO}_{3}{ }^{-}$ \\
$(\mathrm{mg} / \mathrm{L})$ \\
\end{tabular} & $\begin{array}{c}\mathrm{Cl}^{-} \\
(\mathrm{mg} / \mathrm{L}) \\
\end{array}$ & \begin{tabular}{|c|}
$\mathrm{SO}_{4}^{2-}$ \\
$(\mathrm{mg} / \mathrm{L})$ \\
\end{tabular} & $\begin{array}{c}\mathrm{NO}_{3}^{-} \\
(\mathrm{mg} / \mathrm{L})\end{array}$ & $\begin{array}{c}\mathrm{Na}^{+} \\
(\mathrm{mg} / \mathrm{L}) \\
\end{array}$ & $\begin{array}{c}\mathrm{K}^{+} \\
(\mathrm{mg} / \mathrm{L})\end{array}$ & $\begin{array}{c}\mathrm{Ca}^{2+} \\
(\mathrm{mg} / \mathrm{L}) \\
\end{array}$ & \begin{tabular}{|c|}
$\mathrm{Mg}^{2+}$ \\
$(\mathrm{mg} / \mathrm{L})$ \\
\end{tabular} & \begin{tabular}{|l|}
$\mathrm{SiO}_{2}$ \\
$(\mathrm{mg} / \mathrm{L})$ \\
\end{tabular} & $\begin{array}{c}\text { 計 } \\
\text { (mg/L) }\end{array}$ \\
\hline 1 & 大平の湧水 & 三好市大平 & 710 & $S p$ & 031010 & 68.0 & 12.2 & 7.0 & 14.6 & 2.2 & 6.7 & 0.0 & 5.6 & 0.0 & 4.3 & 0.5 & 23.6 & 57.5 \\
\hline 2 & 金 矵刂 滝 & 三好市加茂野宮 & 300 & $s$ & 050430 & 230.0 & 16.5 & 7.8 & 89.0 & 6.0 & 43.2 & 3.3 & 20.9 & 2.0 & 28.9 & 1.6 & 25.4 & 220.3 \\
\hline 3 & & つるぎ町 & 240 & $\mathrm{~s}$ & 050430 & 92.0 & 16.0 & 7.2 & 42.7 & 2.5 & 9.0 & 0.3 & 4.2 & 0.9 & 12.0 & 1.4 & 10.3 & 83.3 \\
\hline 4 & 闌定の滝 & 美馬 & 140 & 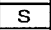 & 30 & 09.0 & 14.5 & 7.0 & 39.0 & 2.6 & 13.9 & 0.2 & 3.8 & 0.8 & 13.8 & .2 & 8.5 & 83.8 \\
\hline 5 & 川瀬の水 & 美菫 & 220 & $S p$ & 0 & 0 & 16.5 & 7.6 & 2.7 & 2.9 & 38.0 & 1 & 2 & 1.2 & 6.1 & 3 & 17.1 & 196.6 \\
\hline 6 & 江川の湧水 & 吉里 & 15 & $S p$ & 0 & 2.0 & 18.0 & 6.6 & 53.6 & 4.0 & 11.1 & 5 & 5.8 & 1.5 & 7.9 & 3.5 & 10.8 & 117.7 \\
\hline 7 & 龍 王 水 & 吉里 & 50 & $\mathrm{pp}$ & & 9.5 & 19.2 & 7.2 & 100.0 & 5.8 & 13.2 & 0.1 & 3.3 & 0.5 & 2 & 1.0 & 6.2 & 4.3 \\
\hline 8 & 黄金の井户 & 板野 & 25 & Gw & 0 & 0 & 19.0 & 6.6 & 64.6 & 9.9 & 12.6 & 0.0 & 18.8 & 1.2 & 2 & 2.6 & 4.0 & 4.9 \\
\hline 9 & 面影の井戸 & 德島 & 5 & Gw & 3 & 4.0 & 17.0 & 6.8 & 68.3 & 5.3 & 15.4 & 7.1 & 4.7 & 0.7 & 0.3 & 5.5 & 11.9 & .2 \\
\hline 10 & 蔵清 水 & 德島 & 3 & $S p$ & 991 & 6.0 & 17.0 & 6.8 & 69.5 & 6.3 & 15.8 & 6.1 & 4.9 & 0.9 & 20.0 & 5.5 & 12.7 & 1.7 \\
\hline & 蔵 清 水 & 德 & 3 & $S p$ & 051 & 0.0 & 15.0 & 7.6 & 64.6 & 4.6 & 14.1 & 4.8 & 6.4 & 0.0 & 17.9 & 5.4 & 14.1 & 1.9 \\
\hline 11 & 桐 $の$ 水 & 德宦 & 90 & $S p$ & 051108 & 190.0 & 14.2 & 7.7 & 90.2 & 7.5 & 3.4 & 9.7 & 7.1 & 0.0 & 6 & 10.0 & 8.1 & 2.6 \\
\hline 12 & 錦 竜 水 & 德島 & 3 & $S p$ & 991022 & 239.0 & 16.6 & 7.2 & 100.0 & 10.8 & 5.6 & 3.7 & 5.6 & 0.2 & 21.5 & 9.2 & 16.5 & 173.1 \\
\hline & 錦 竜 水 & 德島 & 3 & $S p$ & \begin{tabular}{|l|}
51108 \\
\end{tabular} & 210.0 & 15.0 & 7.6 & 101.2 & 11.0 & 6.2 & 4.3 & 8.2 & 0.0 & 21.8 & 10.0 & 18.7 & 181.4 \\
\hline 13 & 凰翔水（瑞 & 德島 & 5 & $S p$ & 991022 & 260.0 & 17.3 & 7.3 & 128.1 & 9.8 & 4.7 & 1.9 & 6.7 & 0.3 & 29.4 & 8.3 & 16.9 & 206.1 \\
\hline & 腺翔水(瑞籍寺) & 德島 & 5 & $S p$ & 051108 & 230.0 & 16.0 & 7.8 & 130.5 & 9.7 & 5.6 & 2.2 & 9.4 & 0.0 & 29.7 & 8.9 & 19.2 & 215.2 \\
\hline 14 & 大泉小泉 & 神山 & 40 & $S p$ & 051121 & 110.0 & 14.0 & 7.6 & 52.4 & 3.5 & 6.5 & 1.6 & 3.9 & 0.1 & 14.4 & 3.2 & 12.8 & 98.4 \\
\hline 15 & 柳 の 水 & 神山 & 490 & $S p$ & 051 & 47.0 & - & 5.2 & 4.8 & 3.7 & 13.2 & 0.1 & 6.0 & 0.1 & 0.8 & 0.7 & 21.1 & 0.5 \\
\hline 16 & の中川（忽 & 神山 & 730 & $S p$ & 050 & 44.0 & 12.5 & 6.8 & 21.9 & 2.0 & 2.0 & 0.2 & 3.8 & 0.1 & 2.7 & 1.2 & 9.7 & 43.6 \\
\hline 17 & 川原高原 & 佐那 & 730 & $S p$ & 050 & 66.0 & 12.5 & 6.8 & 36.6 & 2.9 & 1.3 & 0.1 & 4.7 & 0.1 & 6.4 & 2.6 & 11.9 & 66.6 \\
\hline 18 & の水 (德 & 佐那 & 570 & $S p$ & 050 & 31.0 & 12.5 & 6.8 & 12.2 & 3.0 & 0.7 & 0.0 & 3.7 & 1.0 & 1.0 & 0.6 & 7.0 & 29.2 \\
\hline 19 & 寿水 (地蔵寺) & 小昖 & & Gf & 051 & 140.0 & 16.0 & 7.5 & 57.3 & 4.1 & 11.0 & \begin{tabular}{l|l}
3.6 \\
\end{tabular} & 5.2 & 0.0 & 11.9 & 7.0 & 14.8 & 114.9 \\
\hline 20 & ぞみの泉 & 小松 & 1 & $\mathrm{Gf}$ & & 130.0 & 16.4 & 6.6 & 52.4 & 4.0 & 9.8 & 2.4 & 3.8 & 0.7 & 10.8 & 5.5 & 11.0 & 100.4 \\
\hline 21 & 見の滝 (星谷寺) & 勝浦 & 260 & $\mathrm{~s}$ & & 73.0 & 15.0 & 7.0 & 35.3 & 3.9 & 3.9 & 0.0 & 4.1 & 0.4 & 8.8 & 2.1 & 10.0 & 68.5 \\
\hline 22 & 吞大師 & 勝浦 & 160 & $S p$ & & 47.0 & 13.4 & 6.7 & 14.6 & 3.6 & 2.5 & 0.3 & 5.6 & 0.1 & 1.1 & 1.4 & 16.4 & 45.6 \\
\hline 23 & 頂ヶ滝 & $1-1$ & 400 & $\mathrm{~S}$ & & 111.0 & 13.0 & 7.2 & 69.5 & 3.3 & 4.5 & 0.6 & 3.6 & 1.0 & 23.8 & 1.3 & 8.5 & 116.1 \\
\hline 24 & 龍寺の水 & 阿南 & 480 & GW & & 53.0 & 16.0 & 6.8 & 24.4 & 3.9 & 3.4 & 0.2 & 5.0 & 0.1 & 3.1 & 0.9 & 11.0 & 52.0 \\
\hline 25 & 水の井戸 (平 & 阿南 & 60 & Gw & & 29.0 & 16.5 & 6.6 & 45.1 & 8.8 & 6.3 & 0.6 & 6.8 & 0.5 & 10.8 & 2.6 & 15.7 & 97.2 \\
\hline 26 & 柱钼音の水 & 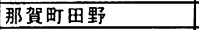 & 50 & $\mathrm{Sp}$ & & 6.0 & 16.0 & 7.0 & 64.6 & 4.6 & 4.4 & 0.1 & 4.8 & 0.0 & 16.2 & 1.4 & 8.7 & 104.8 \\
\hline 27 & ヶ谷渓谷 & & 3 & S & & 99.0 & 12.5 & 6.8 & 52.4 & 2.8 & 6.5 & 0.1 & 4.8 & 0.7 & 12.4 & 1.5 & 7.7 & 88.9 \\
\hline 28 & 御加持水（黒滝寺） & 鿓名 & 76 & $S p$ & & 62.0 & 14.0 & 6.8 & 15.8 & 2.4 & 2.1 & 0.0 & 3.3 & 0.0 & 3.8 & 1.6 & 16.1 & 45.1 \\
\hline 29 & 長 命 水 & & 3 & $S p$ & & 30.0 & 15.5 & 7.4 & 82.9 & 1.7 & 14.4 & 0.1 & 7.7 & 1.0 & 22.0 & 1.9 & 11.0 & 142.7 \\
\hline 30 & 歩危峡の湧水 & & & $S p$ & & 4.0 & 14.2 & 7.2 & 75.6 & 1.6 & 5.9 & 0.0 & 3.1 & 0.0 & 25,0 & 1.0 & 8.6 & 120.8 \\
\hline 31 & 山御神水 & & & $S p$ & & 5.9 & 7.4 & 6.8 & 61.0 & 1.4 & 2.6 & 0.9 & 1.7 & 0.7 & 19.6 & 0.3 & 4.0 & 92.2 \\
\hline & 了御神水 & 越 & & $\mathrm{Sp}$ & & 112.0 & - & 7.2 & 58.5 & 0.8 & 3.5 & 1.1 & 1.2 & 0.3 & 20.6 & 0.3 & 3.9 & 90.2 \\
\hline & 御神水 & 八越 & & $S p$ & & 110.0 & 9.7 & 7.4 & 63.4 & 0.8 & 2.1 & 0.5 & 0.6 & 0.1 & 21.5 & 0.4 & 4.6 & 94.0 \\
\hline 32 & の水場 & 見ノ越 & & $S p$ & 91 & 65.0 & 9.5 & 6.8 & 26.8 & 0.9 & 7.4 & 0.4 & 1.1 & 0.2 & 9.5 & 0.7 & 8.3 & 55. \\
\hline 33 & 次郎笈の水場 & 見ノ越 & 0 & Sp & 01 & 33.0 & 8.5 & 6.7 & 14.6 & 0.6 & 1.8 & 0.0 & 0.8 & 0.1 & 3.9 & 0.6 & 6.5 & 28. \\
\hline 34 & 京柱虾の水 & 三好i & 1100 & $\mathrm{Sp}$ & 010901 & 49.5 & 15.1 & 7.0 & 21.9 & 1.9 & 2.9 & 1.5 & 0.7 & 0.1 & 5.2 & 2.1 & 9.1 & 45.4 \\
\hline 35 & 褒の滰 & 海陽町平井 & 300 & $\mathrm{R}$ & 051113 & 61.0 & 11.0 & 6.7 & 23.1 & 2.2 & 4.7 & 0.0 & 3.3 & 0.0 & 5.6 & 0.9 & 7.7 & 47.5 \\
\hline 36 & 海 部 川 & 筜ノ瀬 & 90 & $\mathrm{R}$ & 991023 & 61.0 & 17.0 & 6.8 & 24.4 & 2.1 & 4.2 & 0.0 & 2.7 & 0.3 & 5.9 & 0.7 & 8.8 & 49. \\
\hline 37 & 皆ノ瀬の水 & 宵/瀬 & 80 & $S p$ & 991023 & 59.7 & 14.7 & 6.6 & 23.1 & 2.2 & 3.3 & 0.0 & 2.6 & 0.2 & 5.8 & 0.7 & 10.8 & 48. \\
\hline 38 & 肺大師の水（薬王寺) & 河内 & 20 & GW & 050429 & 104.0 & 16.5 & 6.4 & 51.2 & 8.9 & 4.7 & 0.0 & 13.2 & 1.1 & 6.8 & 2.2 & 38.5 & 126.6 \\
\hline 39 & 満石神社 & 美波 & 10 & $S p$ & 051113 & 200.0 & 17.8 & 5.9 & 8.5 & 49.2 & 7.3 & 4.2 & 28.8 & 1.1 & 2.5 & 4.8 & 21.9 & 128. \\
\hline 40 & 御水大師 & 美波町阿部 & 40 & $S p$ & 031010 & 130.0 & 18.0 & 7.0 & 14.6 & 19.2 & 4.8 & 0.0 & 13.1 & 0.5 & 4.1 & 1.9 & 28.1 & 86.3 \\
\hline
\end{tabular}

[水源 : $\mathrm{Sp}=$ 湧水， $\mathrm{S}=$ 溪流水， $\mathrm{R}=$ 河川水， $\mathrm{GW}=$ 浅井戸の水， $\mathrm{Gf}=$ 自噴水] 
定の滝（No.4）の水は鳴滝の水に似ているが、 $\mathrm{Ca}$ と $\mathrm{SO}_{4}$ 成分の割合がやや多く、 $\mathrm{Ca}-\mathrm{HCO}_{3}$ 型に $\mathrm{Ca}-\mathrm{SO}_{4}$ 型が加わったタイプである。川瀬の水 （No. 5 ）については、 $\mathrm{Ca} \cdot \mathrm{HCO}_{3} \cdot \mathrm{SO}_{4}$ などの溶存 成分量が多く、組成としては $\mathrm{Ca}-\mathrm{HCO}_{3}$ 型に $\mathrm{Ca}-$ $\mathrm{SO}_{4}$ 型が加わったタイプである。

江川の湧水 (No.6) は $\mathrm{Ca}$ と $\mathrm{HCO}_{3}$ 成分の割合が 高く、組成としては $\mathrm{Ca}-\mathrm{HCO}_{3}$ 型を示している。 そして、 $\mathrm{NO}_{3}$ 成分の濃度が $9.5 \mathrm{mg} / \mathrm{L}$ と、採水した サンプルの中では 2 番目に高いのも特徴的であっ た。ところで、この江川の湧水については、水温 異常の他に、水質組成も季節変化し、夏期の 7 . 8 月に溶存成分量が増加することも知られてい て、特に $\mathrm{Ca}$ と $\mathrm{NO}_{3}$ 成分が増加すると指摘されて いる（島野・永井、1995）。この時の採水は10月で あり、濃度が下がった時点のものであったが、 $\mathrm{NO}_{3}$ 成分については少し濃度が高かった。龍王水 (No.7) は、 $\mathrm{Ca}$ と $\mathrm{HCO}_{3}$ 成分の割合がかなり高 く、組成としては $\mathrm{Ca}-\mathrm{HCO}_{3}$ 型を示していた。

金泉寺の黄金の井戸 (No.8) の水は、 $\mathrm{Na}$ と. $\mathrm{HCO}_{3}$ 成分の割合がかなり高く、組成としては $\mathrm{Na}-\mathrm{HCO}_{3}$ 型を示している。井戸寺の面影の井戸 (No.9) と蔵清水 (No.10) は、ともに鮎喰川の沖 積地に位置していて、よく似た組成を示し水質型 としては $\mathrm{Ca}-\mathrm{HCO}_{3}$ 型である。眉山山麓部に位置 する桐の水 (No.11) ·錦竜水 (No.12) ·鳳翔水 （No.13）については、溶存成分量がやや多い湧水 である。いずれも $\mathrm{Ca} \cdot \mathrm{Mg}$ と $\mathrm{HCO}_{3}$ 成分の割合がか なり高く、組成としては $\mathrm{Ca}(\mathrm{Mg})-\mathrm{HCO}_{3}$ 型を示し ている。なお、桐の水で $\mathrm{NO}_{3}$ 成分が $9.7 \mathrm{mg} / \mathrm{L}$ と、 採水したサンプルの中では一番濃度が高かった。

大泉小泉 (No.14) の水は、 $\mathrm{Ca}$ と $\mathrm{HCO}_{3}$ 成分を中 心として適度に溶存成分量を含み、組成としては $\mathrm{Ca}-\mathrm{HCO}_{3}$ 型を示している。柳の水（No.15）は成 分量のかなり少ない水で、組成は $\mathrm{Na}-\mathrm{SO}_{4}$ 型を示 していた。しかし、別のサンプルをみると（池 田、2005)、溶存成分量がもう少し多く、 $\mathrm{Ca}^{-}$ $\mathrm{HCO}_{3}$ 型を示していた。この違いについては、 我々の採水時での湧水が少なく、雨水によって薄 められた結果であると考えられ、本来はもう少し 成分量が多いものと思われる。悲願寺の天の中川 (No.16) · 大川原高原の水 (No.17) と徳円寺の命 の水（No.18）は、ともに剣山系東部に位置する
山々の北斜面中腹部に位置する湧水であり、溶存 成分量についてはともに少ない。水質組成は天の 中川と大川原高原の水が $\mathrm{Ca}-\mathrm{HCO}_{3}$ 型、命の水が $\mathrm{Na}-\mathrm{HCO}_{3}$ 型と、少し異なる。

小松島市の宝寿水(No.19) とのぞみの泉 (No.20) の 2 つの自噴水は、ともに $\mathrm{Ca} \cdot \mathrm{Mg}$ と $\mathrm{HCO}_{3}$ 成分の割合が高く、組成としては $\mathrm{Ca}(\mathrm{Mg})$ $\mathrm{HCO}_{3}$ 型を示している。星谷寺の裹見の滝 （No.21）の水は、溶存成分量がやや少ない水で、 組成としては $\mathrm{Ca}-\mathrm{HCO}_{3}$ 型を示している。水吞大 師（No.22）の水も溶存成分量が少ない水で、組成 は命の水（No.18）に似ていて、 $\mathrm{Na}-\mathrm{HCO}_{3}$ 型を呈 していた。灌頂ヶ滝 (No.23) の水は、 $\mathrm{Ca}$ と $\mathrm{HCO}_{3}$ 成分の割合が高く、 $\mathrm{Ca}-\mathrm{HCO}_{3}$ 型を示している。

山の上に位置する太龍寺の水 (No.24) も溶存成 分量が少なく、組成は $\mathrm{Na}-\mathrm{HCO}_{3}$ 型をしていた。 平等寺の白水の井戸 (No.25)、水柱観音の水 （No.26）抢よび臼ヶ谷渓谷（No.27）の水は、とも に $\mathrm{Ca}$ と $\mathrm{HCO}_{3}$ 成分の割合が高く、組成は $\mathrm{Ca}^{-}$ $\mathrm{HCO}_{3}$ 型を示していた。黑滝寺の御加持水 （No.28）は、溶存成分量がやや少ないが、組成は $\mathrm{Ca}-\mathrm{HCO}_{3}$ 型である。長命水（No.29）と歩危峡の 湧水（No.30）は、ともに川沿いに位置する湧水 で、溶存成分量がかなり多いが、組成はやはり $\mathrm{Ca}-\mathrm{HCO}_{3}$ 型であった。

剣山御神水 (No.31) は石灰岩質の地質を反映し た水質組成で、典型的な $\mathrm{Ca}-\mathrm{HCO}_{3}$ 型を示してい る。剣山の水場 (No.32) ·次郎笈の水場 (No.33) については、ともに溶存成分量が少なく、組成は $\mathrm{Ca}-\mathrm{HCO}_{3}$ 型であった。京柱峠の水（No.34）も溶 存成分量が少なく、組成は若干異なり $\mathrm{Ca}(\mathrm{Mg})-$ $\mathrm{HCO}_{3}$ 型である。そして、県の南西部に位置する 轟の滝（No.35）・海部川（No.36）・皆ノ瀬の水 （No.37）については、ともに溶存成分量が少な く、組成としては $\mathrm{Ca}-\mathrm{HCO}_{3}$ 型を示していた。

薬王寺の肺大師の水 (No.38) は、 $\mathrm{Na} \cdot \mathrm{Ca}$ と $\mathrm{HCO}_{3}$ 成分の割合がかなり高く、組成としては $\mathrm{Na}-\mathrm{HCO}_{3}$ 型に $\mathrm{Ca}-\mathrm{HCO}_{3}$ 型が加わったタイプを示 している。沿岸部に位置する满石神社 (No.39) の 水は、 $\mathrm{Na}$ と $\mathrm{Cl}$ 成分の割合が非常に高く、 $\mathrm{Na}-\mathrm{Cl}$ 型と海水の影響を受けた組成を示している。御水 大師（No.40）の水も $\mathrm{Na}$ と Cl 成分の割合が高く、 組成としては $\mathrm{Na}-\mathrm{Cl}$ 型を呈していた。 
地下水学会誌 第48巻第 3 号 183 196（2006）

採水した地点の大部分では $\mathrm{Ca}-\mathrm{HCO}_{3}$ 型ないし は $\mathrm{Ca}(\mathrm{Mg})-\mathrm{HCO}_{3}$ 型の組成を示していたが、 $\mathrm{Na}^{-}$ $\mathrm{HCO}_{3}$ 型や $\mathrm{Na}-\mathrm{HCO}_{3}$ と $\mathrm{Ca}-\mathrm{HCO}_{3}$ の混合タイプ、そ れに $\mathrm{Na}-\mathrm{Cl}$ 型および $\mathrm{Ca} \cdot \mathrm{Na}^{-} \mathrm{HCO}_{3} \cdot \mathrm{SO}_{4}$ 型なども
みられた。な扮、地下水污染の指標になっている $\mathrm{NO}_{3}$ 成分については、最高でも濃度が $9.7 \mathrm{mg} / \mathrm{L} 、 5$ $\mathrm{mg} / \mathrm{L}$ 超えたのが 4 カ所であり、大部分は 1 $\mathrm{mg} / \mathrm{L}$ 以下と心配のいらない状態であった。
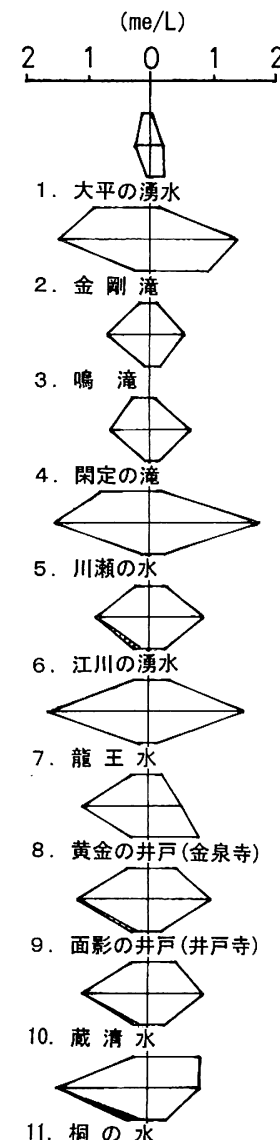

ㄱ․ำ

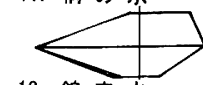

12. 錦 竜水

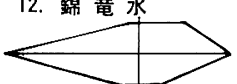

13. 風翔水(瑞蔽寺)

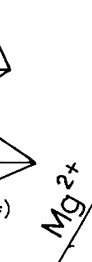

14. 大泉小

15. 㧕 の水

A

16. 天の中川 (悲願寺)

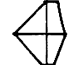

17. 大川原高原の水

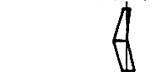

18. 命の水 (徳円寺)

19. 宝寿水(地荿寺)

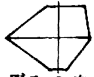

20. のぞみの泉

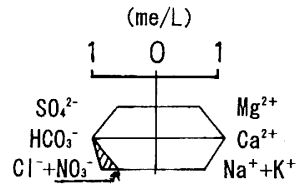

凡 例

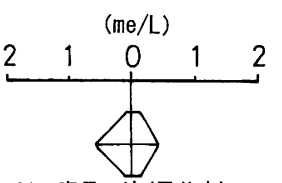

21. 亭見の滰 (星谷寺)

22. 水吞大師

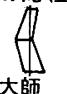

23.

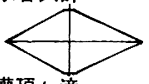

滰

24.

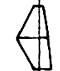

太龍寺の水

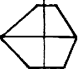

25. 白水の井户 (平等寺)

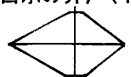

26. 水柱镜音の水

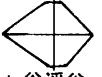

27. 臼ヶ谷溪谷

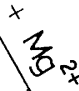

so

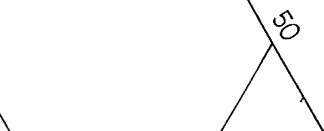

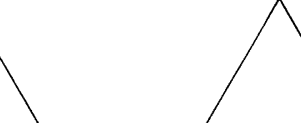

$32 \Delta^{5}$

$\Delta^{5}$
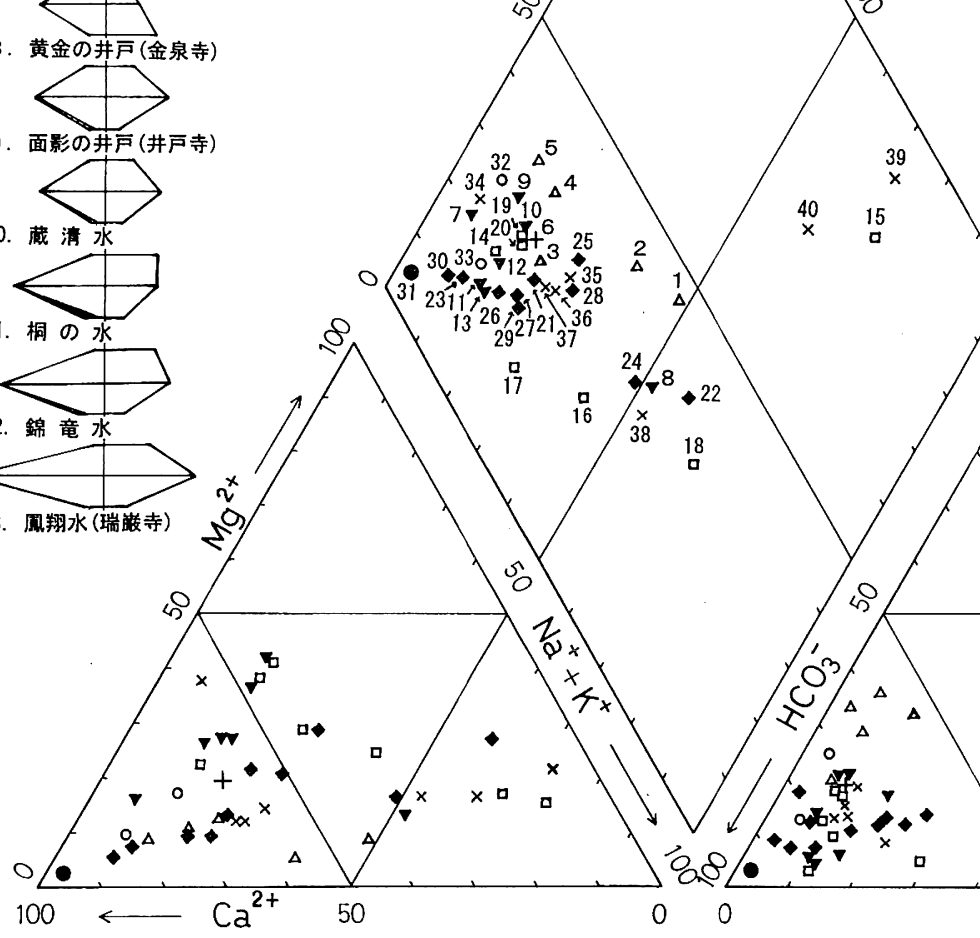

0
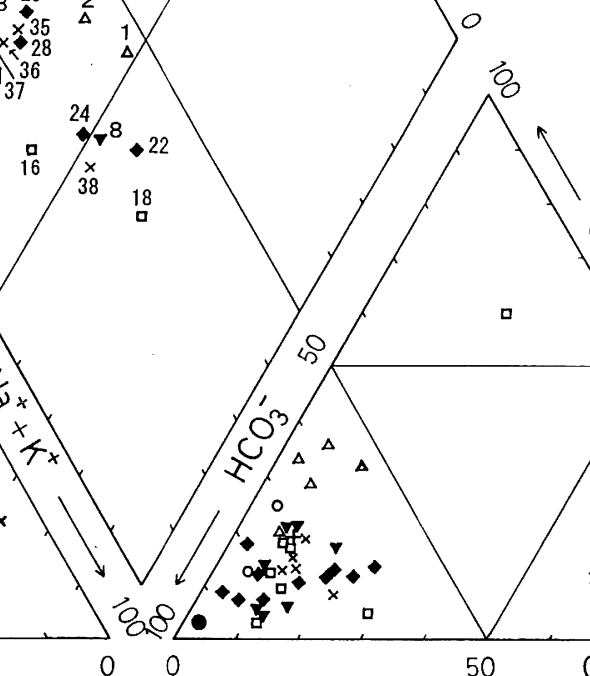

. 肺大師の水 (薬王寺)
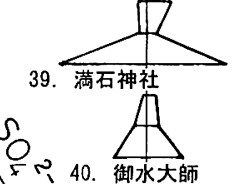

図 6 水質組成図 


\section{5.おわりに}

徳島県の湧水・井戸水・溪流水などに関してみ てきたが、一部を除き大部分の水は清水・清流に 值するものであった。これには山がちな地形の上 に、多くの雨が降り、かつ水源域には工場などの 産業活動に関連する施設類が少ないこと、および 地域住民らの自然環境に対する保全・保護活動な ども関係しているものと考えられる。なお、車で 剣山系に位置する湧水や渓流水などの地点を巡っ てみると、一級国道とはいえ、かなり曲がりく ねっていて、かつ道幅の狭い所が多く、すれ違い などに苦労をした所もあった。これも山がちで渓 谷の多い地形のなせることであり、それだけ自然 環境に恵まれているという反語かもしれない。

ところで、今回は灌頂ヶ滝 (No.23) という町の 入口近くの場所にある滝に詣でたのみであるが、 この上勝町に関して少し触れておくことにする。 勝浦川上流域に位置する上勝町は、もとは林業を 主とする山奥の普通の町であった。しかし近年、 「木の葉を金に変えた町」として有名になってい る一方で、「ゴミゼロ宣言」を公表し、2020年ま でにゴミをゼロにする町としても知られていて、 年に 4000 人もの人々が見学に訪れているという。 水源域でこうした取り組みを行う自治体および地 域住民については、今後の自然環境保全の在り方 として見習う点が多々あるように思えた。

\section{謝辞}

水質分析に関して、2005年に採水したサンプルにつ いては筑波大学陸域環境研究センターの藪崎志穂さん にお手伝いを頂きました。記して感謝の意を表します。

\section{文献}

新井 正・佐倉保夫（1980）：最近江川の異常水温につ いて，ハイドロロジー、10、2-11.

新井 正・横畠道彦 (1990)：徳島県江川付近の地下水 の温度と流動。地理学評論、63A、343-355.

新井 正 (1991)：名水を訪ねて（16）江川湧水. 地下 水学会誌、33(4)、285-290.

池田早苗 (2005): 德島県はおいしい水の宝庫. 天の水. 地の水（全国地下水利用対策団連合会）、155号、3045.

井内國光（2005）：吉野川流域の地下水と海岸部におけ る塩水化現象について，天の水·地の水（全国地下水 利用対策団連合会)、155号、19-29.

井内國光・重松和恵 - 柿沼忠男 (1993)：名水を訪ねて

（21）愛媛県の名水. 地下水学会誌、35(1)、53-58. 太田陽子ほか 3 名編著（2004）：日本の地形 6 -近畿 ·

中国・四国．東京大学出版会、383p.

環境庁監修 (1985): 名水百選.ぎょうせい、172p.

河野忠（2002）：名水を訪ねて（59）高知県の名水.

地下水学会誌、44(4)、325-335.

新見 治（1999）：名水を訪ねて（47）香川県の名水.

地下水学会誌、41(4)、337-345.

須鎗和巳-岩崎正夫·鈴木克士（1991）：日本の地質 8 .

四国地方．共立出版、266p.

地質調查所（1992）：100万分の 1 日本地質図.

堤 岑生 (2005): 吉野川流域地下水位の今昔. 天の水. 地の水（全国地下水利用対策団連合会）、155号、1218.

徳島県 (1999)：とくしま水紀行50選. 32p.

（受付：2006年 6 月 1 日、受理：2006年 6 月17日） 


\section{徳島県の名水}

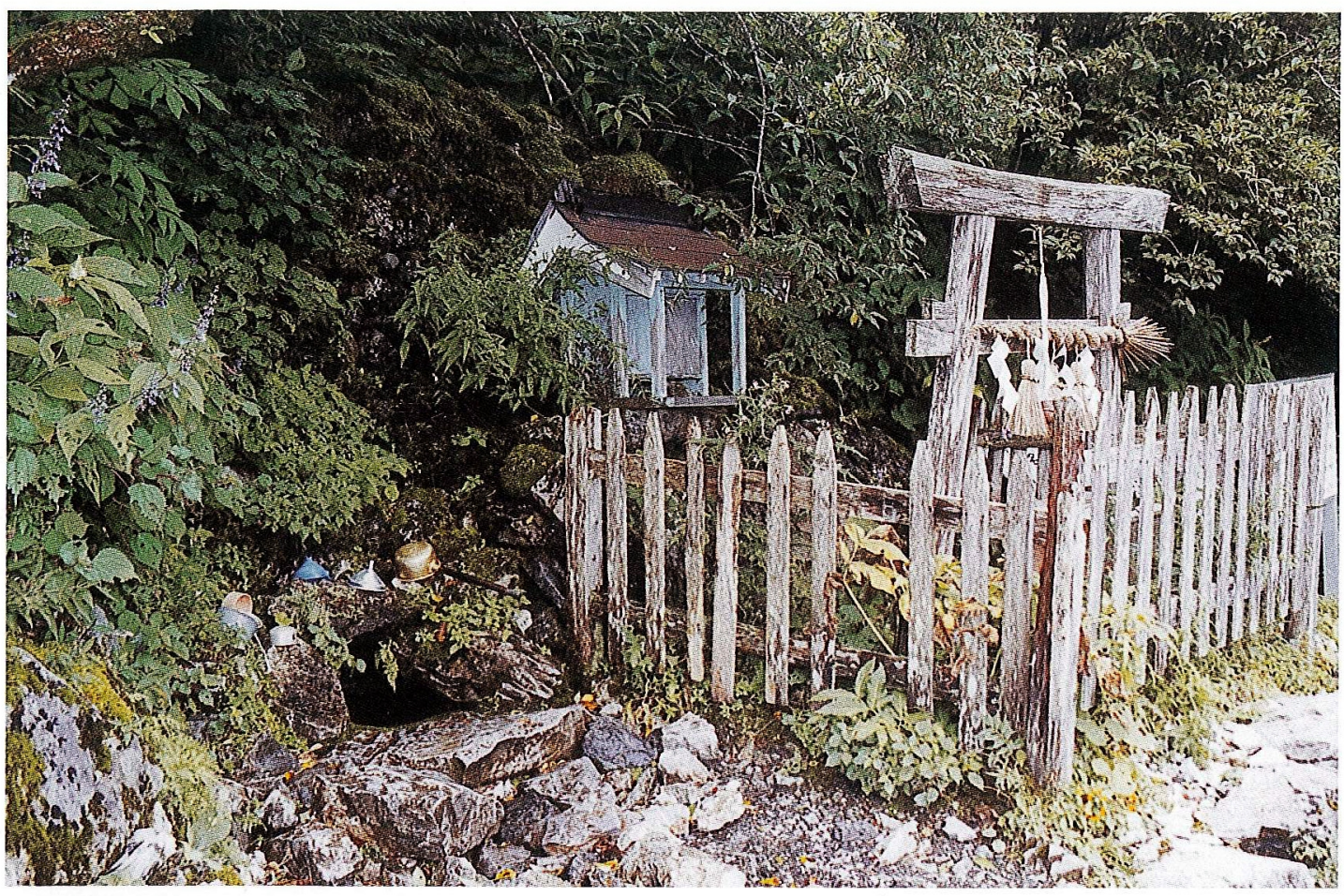

$A$ 剣山御神水

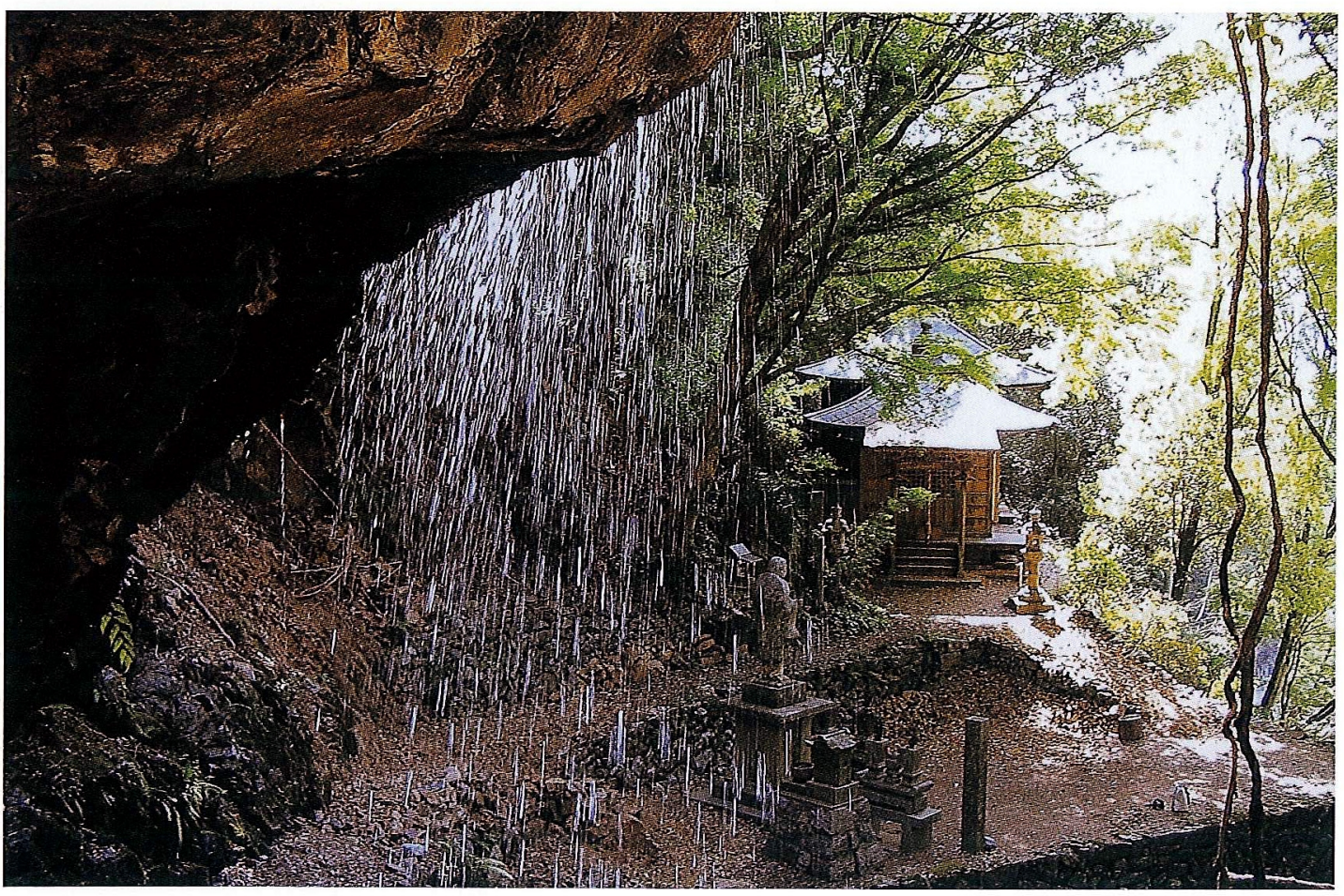

$\mathrm{B}$ 裏見の滝（星谷寺）

（写真提供：島野安雄） 